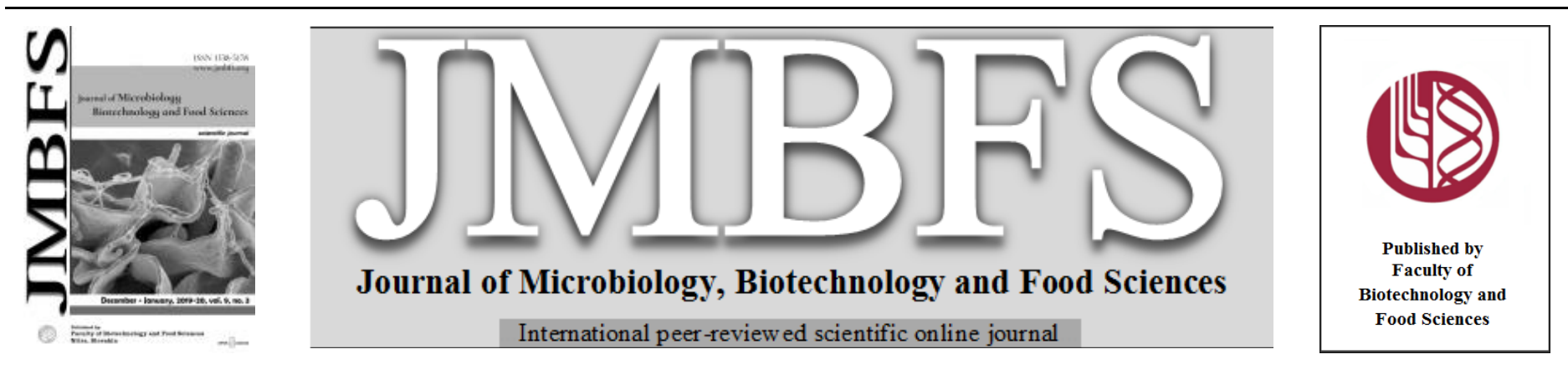

\title{
PARTIAL WHEAT FLOUR REPLACEMENT WITH GLUTEN-FREE FLOURS IN BREAD - QUALITY, TEXTURE AND ANTIOXIDANT ACTIVITY
}

\author{
Adamina Duda ${ }^{1}$, Pawet Jeżowski², Dominika Radzikowska ${ }^{3}$, Przemysław Lukasz Kowalczewski \\ Address(es): Dr. Przemysław Kowalczewski, \\ ${ }^{1}$ Students' Scientific Club of Food Technologists, Poznań University of Life Sciences, 31 Wojska Polskiego Str., 60-624 Poznań, Poland. \\ ${ }^{2}$ Institute of Chemistry and Technical Electrochemistry, Poznan University of Technology, 4 Berdychowo Str., 60-965 Poznań, Poland. \\ ${ }^{3}$ Department of Agronomy, Poznań University of Life Sciences, 11 Dojazd Str, 60-632 Poznań, Poland. \\ ${ }^{4}$ Institute of Food Technology of Plant Origin, Poznań University of Life Sciences, 31 Wojska Polskiego Str., 60-624 Poznań, Poland.
}

*Corresponding author: przemyslaw.kowalczewski@up.poznan.pl

doi: 10.15414/jmbfs.2019/20.9.3.505-509

\section{ARTICLE INFO}

Received 27. 2. 2019

Revised 4. 5. 2019

Accepted 12. 5. 2019

Published 1. 12. 2019

Regular article

OPEN $\partial_{\text {ACCESS }}$

\begin{abstract}
Consumers are increasingly looking for products in which gluten is not present or its content has been reduced by the conversion of conventional raw materials to gluten-free. The influence of the partial wheat flour replacement (from $10 \%$ to $40 \%$ ) with gluten-free flours from amaranth, quinoa and millet on bread properties, including texture and crumb structure of the final product, as well as antioxidant potential and consumer acceptance were evaluated. The effect of replacement on pasting properties of flours mix was determined as well. It was found that the increased addition of millet and quinoa flours resulted in an increased maximum viscosity, whereas adding amaranth flour exerted an opposite effect. The wheat flour replacement influenced the colour of the product reducing its lightness and shifting colour balances as well. Due to a lower content of gluten proteins in the bread formulation the firmness of the crumb increased. Wholemeal flours are good source of antioxidants, antioxidant activity increased with a higher proportion of glutenfree flours.
\end{abstract}

Keywords: texture, crumb structure, bread quality, gluten-free flours addition, antioxidant properties

\section{INTRODUCTION}

Bread is often a staple of the diet and it is consumed almost every day around the world. The bread satisfies about $10 \%$ of the daily requirement of such ingredients as proteins, niacin, folic acid, thiamine, iron, copper, zinc and magnesium. In addition, it satisfies the demand for fiber and calcium in 20\% (Grafenauer and Curtain 2018; Lamacchia et al. 2018; O'Connor 2012). Due to the universal nature, bread can be enriched with many nutrients, which can contribute to the elimination of nutrient deficiencies. The use of unconventional ingredients also allows to vary the sensory characteristics. Among such ingredients, whole-whea gluten-free flours are particularly noteworthy, in particular from amaranth, millet and quinoa. It is worth noting, however, that gluten is a fundamental structure in bread production and is responsible not only for the appearance or structure, but also the consumers acceptance of bakery products (Rybicka et al. 2019). The high nutritional value and pro-health properties must be accompanied by sensory attractiveness (Sun-Waterhouse and Wadhwa 2013).

Amaranth, more and more often referred to as the crop of the $21^{\text {th }}$ century, is a plant indigenous to South America. Common on all continents, it is known under different names and used for various purposes. The nutritional value of amaranth seeds is much higher than that of seeds of other crops. Amaranth flour contains significant amounts of protein, fiber and valuable fatty acids necessary for the proper functioning of the body. It is also a source of mineral compounds (calcium, phosphorus, iron), as well as vitamins (B1, B2, B3, B9, A, C, PP) (Venskutonis and Kraujalis 2013). The proportion of protein, one of the most vital elements of the seed, is about $16 \%-20 \%$. The biological value of the protein is high considering the nutritional benefits that it can provide. The nutritional value of amaranth exceeds the value of soy protein as it is rich in all essential amino acids. Amaranth protein has an even higher biological value than milk protein (Escudero et al. 2004). An important advantage of amaranth flour is the high content of the limiting amino acid in most cereal products - lysine (Ayo 2001; García Salcedo et al., 2018). Amaranth seeds additionally contain numerous mono- and polyunsaturated fatty acids, including GLA ( $\gamma$-Linolenic acid), a health-promoting acid especially valuable for its hypotensive effect (Mondal et al. 2016). Millet seeds contain a high proportion of carbohydrates, amounting to $60-80 \%$, and about $11 \%$ of protein. The exceptional nutritional value of millet protein can be attributed to the essential amino acids such as leucine, isoleucine and methionine, as well as to high content of lecithin. Millet is a valuable source of mineral salts, including potassium, iron and magnesium. Vitamins, including $\mathrm{B}_{1}, \mathrm{~B}_{2}, \mathrm{~B}_{6}, \mathrm{PP}$, biotin, pantothenic acid and folacin are also found in relatively high proportions (Kalinova and Moudry 2006). Quinoa will be popular because of its nutritional value (high content of protein and minerals, including phosphorus, iron and calcium), as well as undemanding growing conditions (resistance to changing weather conditions, alkaline soil $\mathrm{pH}$ or low rainfall) (García Salcedo et al. 2018). The seeds are rich in vitamin $\mathrm{B}_{2}$ (riboflavin), vitamin E, and contain more calcium, magnesium and phosphorus than other cereals. Phytoestrogens in quinoa are known as substances preventing atherosclerosis, breast cancer and osteoporosis (Comai et al. 2007). With the protein content of $14-18 \%$ it is more valuable in this respect than wheat, rice, oats and maize.

Recently, scientific research has been focusing on the effects of free radicals, particularly the reactive oxygen species (ROS), on the human body. Oxidative stress, understood as the imbalance between the ROS activity and antioxidants, may lead to many chronic diseases, as radicals react with proteins, fats and the DNA. Permanent damage as a consequence of the reactions may result in cardiovascular diseases (especially atherosclerosis), macular degeneration, cataract, Parkinson's and Alzheimer's disease, and cancers (Brewer 2007; Cadet et al. 2005; De Flora and Izzotti 2007; Perry et al. 2002; Valko et al. 2006). Therefore, scientists are urgently searching for bioactive compounds to counteract the negative effects of free radicals in humans. Using wholemeal flour in bakery products is likely to increase the proportion of phenolic compounds and antioxidant potential of bread as well. Available literature data suggest that not only whole quinoa seeds but also decorticated and milled fractions of seeds may serve as functional ingredients of gluten-free foods thanks to phenolic acids (vanillic and ferulic acid) and flavonoids (rutin, quercetin). Millet seeds are also rich in phenolic acids like gallic and syringic acid. The content of phenolic compounds in seeds is, however, dependent on the crop conditions and variety (Hemalatha et al. 2016; Seifried et al. 2007).

The present study aimed at evaluating the effect of various proportions of different types of gluten-free flours (amaranth, millet and quinoa flours) on the quality, crumb texture, and antioxidant properties of wheat bread. 


\section{MATERIAL AND METHODS}

\section{Materials}

Wheat flours (WF) was obtained from mill Komplexmłyn sp. z o.o. (Poland) Wholemeal millet flour (WMF), wholemeal quinoa flour (WQF) and wholemeal amaranth flour (WAF) were purchased from Grano Mill (Poland). The characteristics of the flours used are shown in Table 1, according to the producers' data. Salt was bought from Kłodawa S.A. (Poland), compressed baker's yeasts from Lesaffre Polska S.A. (Poland).

Table 1 Basic characteristics of the flours

\begin{tabular}{lllll}
\hline Parameter & WF & WMF & WQF & WAF \\
\hline Carbohydrates [\%] & 70.8 & 70.1 & 70.0 & 61.5 \\
Fat [\%] & 1.3 & 3.2 & 5.8 & 7.7 \\
Fiber [\%] & 2.2 & 1.9 & 6.0 & 12.8 \\
Protein [\%] & 10.6 & 11.0 & 5.8 & 15.1 \\
\hline
\end{tabular}

\section{Dough preparation and baking}

Wheat bread dough (control sample C) was prepared using the following ingredients: $500 \mathrm{~g}$ of plain wheat flour $7.5 \mathrm{~g}$ of salt, $15 \mathrm{~g}$ of yeasts and $300 \mathrm{~g}$ of tap water. Other variants of bread for analysis contained $10 \%, 20 \%, 30 \%$ and $40 \%$ of wheat flour substitutes: wholemeal millet flour (M10, M20, M30 and M40, respectively), wholemeal quinoa flour (Q10, Q20, Q30, Q40), and wholemeal amaranth flour (A10, A20, A30 and A40). The dough was mixed for 120 seconds using a KitchenAid mixer at the speed of $70 \mathrm{rpm}$, then left to ferment for 60 minutes (fermenter conditions: temperature $30^{\circ} \mathrm{C}$, relative humidity $75 \%$ ). After 30 minutes of fermentation the dough was kneaded. On completion of fermentation, two equal loaves of $450 \mathrm{~g}$ were formed, put on baking forms and kept in the fermenter for another 15 minutes. Finally, the dough was baked at $220^{\circ} \mathrm{C}$ for 30 minutes in an oven MIWE condo (MIWE Michael Wenz GmbH, Germany) (Kowalczewski et al. 2019).

\section{Measurements of gelatinisation of starch by RVA}

Changes in the properties of starch gelatinisation were evaluated using the Rapid Visco Analyser Tec Master (Perten Instruments, Sweden) (Makowska et al. 2014). Each analysis evaluated a wheat and gluten-free flours mix of $3.5 \mathrm{~g}$ and 25 $\mathrm{g}$ of distilled water (taking into account any corrective measures to attain humidity of $14 \%$ ). The proportions of wheat flour and gluten-free flours for every bread variant were in accordance with the dough recipes and were the basis for evaluating the effect of wheat flour substitution. The suspension was stabilised for 1 minute at $50{ }^{\circ} \mathrm{C}$, then the sample was heated at $6{ }^{\circ} \mathrm{C}$ per minute until it reached $95^{\circ} \mathrm{C}$ and kept at this temperature for 5 minutes. After thermostating the sample was cooled to $50{ }^{\circ} \mathrm{C}$ by lowering the temperature by $6{ }^{\circ} \mathrm{C}$ per minute During the process the gelatinisation temperature and viscosity of the paste were measured

\section{Evaluation of the quality of bread}

Measurement of the volume of bread was performed according to AACC 10-05 International Approved Methods (AACC 2009a), moisture content measurement was performed according to AACCI 44-19.01 (AACC 2009b). Additionally, bake loss and yield were calculated (Leuschner et al. 1997).

\section{Analysis of the colour of bread crumb}

The colour characteristics were evaluated using the Chroma Meter CR-410 by Konica Minolta Sensing Inc. (Japan) in the CIE L*a*b* colour space (Pauter $\boldsymbol{e} t$ al. 2018). Lightness of the sample $\left(\mathrm{L}^{*}\right)$ and colour saturation were measured: $\mathrm{a}^{*}$ red (+) / green (-), and b* - yellow (+) / blue (-). The Total Colour Difference (TCD) was calculated on the basis of the measurements, according to the following formula:

$$
\Delta \mathrm{E}=\sqrt{\Delta \mathrm{L}^{* 2}+\Delta \mathrm{a}^{* 2}+\Delta \mathrm{b}^{* 2}}
$$

\section{Evaluation of the texture of bread crumb}

The texture was determined with a TA.XTplus texture analyser (Stable Micro Systems, UK) (AACC 2009c). For each analysis, a $2.5 \mathrm{~cm}$ crumb sample was taken from the middle of the loaf. The test parameters were: pre-test speed: 1 $\mathrm{mm} / \mathrm{s}$; test speed: $5 \mathrm{~mm} / \mathrm{s}$; post-test speed: $10 \mathrm{~mm} / \mathrm{s}$. To evaluate the firmness of bread, the force required to compress the bread crumb by $25 \%$ was determined.

\section{Evaluation of the structure of bread crumb}

Photographs taken with a GO-3 (QImaging, Canada) camera served as the basis for bread crumb structure analysis. The photographs were compared in the Image-Pro Plus software (Media Cybernetics Company).

\section{Extraction of bioactive compounds}

The extraction of phenolic and antioxidant compounds from freeze-dried bread was performed using $80 \%(\mathrm{v} / \mathrm{v})$ methanol. The volume to solvent ratio was $1: 5$. The extraction process took 45 minutes using a S50 shaker (CAT, Germany). After 45 minutes of extraction the samples were centrifuged at $7800 \mathrm{~g}$, and the obtained supernatant was decanted from precipitate.

\section{Measurements of antioxidant properties and total phenolics}

Antioxidant properties were measured using the ABTS radical cation (Re $\boldsymbol{e t}$ al. 1999). Antioxidant activity per 1 gram of dry mass was expressed as the Trolox equivalent antioxidant capacity (TEAC). A spectrophotometric determination of total phenolics was performed with the Folin - Ciocalteu reagent (Fang $\boldsymbol{e t}$ al. 2006). Total phenolic compounds per 1 gram of dry mass were expressed as the ferulic acid equivalent (FAE)

\section{Statistical analysis of the results}

The measurements were subjected to the one-way analysis of variance (ANOVA) using Statistica 10 (StatSoft, Poland) at the 0.05 significance level. To indicate homogenous groups, the post-hoc Tukey HSD test was used.

\section{RESULTS AND DISCUSSION}

Partial substitution of wheat flour with gluten-free flours resulted in changes in starch gelatinisation analysed with RVA (Table 2). In most cases, temperature of starch gelatinisation increased, from $60.7 \pm 0.54{ }^{\circ} \mathrm{C}$ for the control sample, to even $67.2 \pm 0.49^{\circ} \mathrm{C}$ for bread with $40 \%$ of millet flour. Similarly to gelatinisation temperature, the value of viscosity throughout the analysis depends on several factors, such as botanical origin, starch concentration in the mixture, solvent volume, $\mathrm{pH}$ level of the mixture, and presence of other components, for example proteins or hydrocolloids (Hossen et al. 2011; Makowska et al. 2015) Maximum viscosity was found to increase with an increased proportion of millet and quinoa flours added to wheat flour. On the contrary, adding amaranth flour led to a gradual decrease of viscosity.

Table 2 RVA test results

\begin{tabular}{|c|c|c|c|c|c|c|c|}
\hline Sample & $\begin{array}{c}\text { Peak viscosity } \\
{[\mathrm{cP}]}\end{array}$ & $\begin{array}{l}\text { Trough } \\
\text { [cP] }\end{array}$ & $\begin{array}{c}\text { Breakdown } \\
{[\mathrm{cP}]}\end{array}$ & $\begin{array}{c}\text { Final Viscosity } \\
{[\mathrm{cP}]}\end{array}$ & $\begin{array}{c}\text { Seatback } \\
{[\mathrm{cP}]}\end{array}$ & $\begin{array}{c}\text { Peak time } \\
{[\mathrm{s}]}\end{array}$ & $\begin{array}{c}\text { Pasting } \\
\text { Temperature } \\
{\left[{ }^{\circ} \mathrm{C}\right]}\end{array}$ \\
\hline $\mathrm{C}$ & $2156^{\mathrm{b}} \pm 32$ & $1348^{b} \pm 33$ & $807^{\mathrm{c}} \pm 3$ & $2542^{\mathrm{e}} \pm 42$ & $1194^{\mathrm{e}} \pm 9$ & $6.0^{\mathrm{a}} \pm 0.1$ & $60.7^{\mathrm{d}} \pm 0.5$ \\
\hline M10 & $2174^{b} \pm 25$ & $1290^{c} \pm 14$ & $884^{b} \pm 11$ & $2733^{d} \pm 25$ & $1443^{\mathrm{d}} \pm 11$ & $5.8^{\mathrm{c}} \pm 0.1$ & $61.2^{\mathrm{cd}} \pm 0.5$ \\
\hline M20 & $2259^{\mathrm{a}} \pm 25$ & $1306^{\mathrm{bc}} \pm 40$ & $952^{a} \pm 18$ & $2932^{c} \pm 4$ & $1625^{\mathrm{c}} \pm 41$ & $5.9^{b} \pm 0.1$ & $62.0^{c} \pm 0.5$ \\
\hline M30 & $2270^{\mathrm{a}} \pm 72$ & $1219^{\mathrm{cd}} \pm 50$ & $951^{a} \pm 23$ & $3060^{b} \pm 75$ & $1841^{b} \pm 24$ & $5.8^{\mathrm{c}} \pm 0.0$ & $64.3^{b} \pm 0.8$ \\
\hline M40 & $2282^{a} \pm 5$ & $1211^{\mathrm{d}} \pm 9$ & $970^{a} \pm 10$ & $3352^{a} \pm 17$ & $2138^{a} \pm 18$ & $5.7^{\mathrm{d}} \pm 0.0$ & $67.2^{\mathrm{a}} \pm 0.5$ \\
\hline A10 & $1984^{\mathrm{c}} \pm 15$ & $1310^{\mathrm{bc}} \pm 10$ & $674^{e} \pm 37$ & $2486^{\mathrm{f}} \pm 17$ & $1176^{\mathrm{e}} \pm 67$ & $6.0^{\mathrm{a}} \pm 0.1$ & $61.2^{c} \pm 0.5$ \\
\hline A20 & $1864^{\mathrm{c}} \pm 17$ & $1264^{\mathrm{c}} \pm 11$ & $600^{e} \pm 63$ & $2292^{g} \pm 17$ & $1028^{\mathrm{f}} \pm 72$ & $6.0^{\mathrm{a}} \pm 0.1$ & $61.7^{c} \pm 0.8$ \\
\hline A30 & $1662^{\mathrm{d}} \pm 16$ & $1101^{\mathrm{e}} \pm 90$ & $521^{\mathrm{f}} \pm 71$ & $1975^{\mathrm{h}} \pm 14$ & $874^{g} \pm 54$ & $5.8^{c} \pm 0.1$ & $63.2^{\mathrm{b}} \pm 1.0$ \\
\hline $\mathrm{A} 40$ & $1624^{\mathrm{d}} \pm 11$ & $1141^{\mathrm{e}} \pm 68$ & $522^{f} \pm 45$ & $1941^{\mathrm{h}} \pm 97$ & $800^{g} \pm 30$ & $5.7^{\mathrm{d}} \pm 0.1$ & $63.8^{b} \pm 0.4$ \\
\hline Q10 & $2116^{\mathrm{b}} \pm 14$ & $1360^{\mathrm{b}} \pm 10$ & $756^{\mathrm{d}} \pm 4$ & $2596^{\mathrm{e}} \pm 13$ & $1236^{\mathrm{e}} \pm 13$ & $6.0^{\mathrm{a}} \pm 0.1$ & $60.6^{\mathrm{d}} \pm 0.5$ \\
\hline Q20 & $2125^{b} \pm 32$ & $1321^{b} \pm 20$ & $603^{e} \pm 12$ & $2461^{\mathrm{f}} \pm 32$ & $1139^{\mathrm{e}} \pm 14$ & $6.0^{\mathrm{a}} \pm 0.1$ & $61.1^{c} \pm 1.0$ \\
\hline Q30 & $2149^{b} \pm 26$ & $1237^{\mathrm{cd}} \pm 16$ & $511^{\mathrm{f}} \pm 10$ & $2286^{\mathrm{g}} \pm 32$ & $1049^{f} \pm 16$ & $6.0^{\mathrm{a}} \pm 0.2$ & $61.2^{\mathrm{cd}} \pm 0.6$ \\
\hline Q40 & $2222^{a} \pm 51$ & $1446^{a} \pm 24$ & $576^{\mathrm{f}} \pm 26$ & $2614^{\mathrm{e}} \pm 47$ & $1168^{\mathrm{e}} \pm 23$ & $5.9^{\mathrm{b}} \pm 0.0$ & $61.9^{c} \pm 0.9$ \\
\hline
\end{tabular}

Legend: Table shows mean values and standard deviations; mean values in columns denoted by different letters differ significantly $(\mathrm{p}<0.05)$. 
Although gluten-free flour may increase the nutritional value of bread, it may also lead to undesirable structure changes. Bread volume decreased when glutenfree flours were added (Table 3 ), however, a $10 \%$ proportion of millet flour did not result in a significant decrease in volume, compared to the control sample. A smaller content of gluten proteins makes bread smaller and less spongy. Since whole gluten-free seeds are usually milled, the obtained flour has a high fibre content, which inhibits fermentation of the dough and, as a consequence, reduces the volume of a loaf after baking (Sullivan et al. 2011). Substitution of wheat flour with quinoa flour reduced bake loss by about $2 \%$ compared to both the control sample and other mixes of wheat flour with gluten-free flours. Additionally, bread moisture content was lost proportionally to an increased content of gluten-free flours.

Table 3 Quality parameters of analyzed breads

\begin{tabular}{ccccc}
\hline Sample & $\begin{array}{c}\text { Volume of 100 g } \\
\text { loaf } \\
{[\mathbf{m L}]}\end{array}$ & $\begin{array}{c}\text { Bread } \\
\text { yield } \\
{[\%]}\end{array}$ & $\begin{array}{c}\text { Bake loss } \\
{[\%]}\end{array}$ & $\begin{array}{c}\text { Moisture of bread } \\
\text { crumb } \\
{[\%]}\end{array}$ \\
\hline C & $312.4^{\mathrm{a}} \pm 10.2$ & $136.7^{\mathrm{a}} \pm 6.4$ & $7.1^{\mathrm{b}} \pm 0.2$ & $44.35^{\mathrm{a}} \pm 0.64$ \\
M10 & $318.2^{\mathrm{a}} \pm 9.8$ & $138.1^{\mathrm{a}} \pm 5.3$ & $7.2^{\mathrm{b}} \pm 0.4$ & $43.72^{\mathrm{b}} \pm 0.11$ \\
M20 & $280.9^{\mathrm{b}} \pm 4.6$ & $131.7^{\mathrm{b}} \pm 2.9$ & $7.9^{\mathrm{a}} \pm 0.3$ & $42.64^{\mathrm{c}} \pm 0.04$ \\
M30 & $228.1^{\mathrm{c}} \pm 4.7$ & $138.5^{\mathrm{a}} \pm 6.1$ & $6.7^{\mathrm{c}} \pm 0.6$ & $42.45^{\mathrm{c}} \pm 0.03$ \\
M40 & $216.0^{\mathrm{c}} \pm 3.2$ & $135.0^{\mathrm{a}} \pm 3.3$ & $7.2^{\mathrm{b}} \pm 0.3$ & $42.06^{\mathrm{c}} \pm 0.06$ \\
A10 & $279.8^{\mathrm{b}} \pm 2.6$ & $134.5^{\mathrm{a}} \pm 3.1$ & $7.7^{\mathrm{b}} \pm 0.6$ & $44.45^{\mathrm{a}} \pm 0.29$ \\
A20 & $213.8^{\mathrm{c}} \pm 4.1$ & $138.0^{\mathrm{a}} \pm 4.7$ & $7.4^{\mathrm{b}} \pm 0.3$ & $43.82^{\mathrm{b}} \pm 0.40$ \\
A30 & $200.9^{\mathrm{d}} \pm 2.2$ & $130.7^{\mathrm{b}} \pm 4.2$ & $8.0^{\mathrm{a}} \pm 0.5$ & $43.53^{\mathrm{b}} \pm 1.05$ \\
A40 & $140.8^{\mathrm{e}} \pm 6.4$ & $136.7^{\mathrm{a}} \pm 5.8$ & $7.4^{\mathrm{b}} \pm 0.3$ & $42.49^{\mathrm{c}} \pm 0.07$ \\
Q10 & $280.4^{\mathrm{b}} \pm 3.5$ & $137.7^{\mathrm{a}} \pm 5.5$ & $5.3^{\mathrm{d}} \pm 0.3$ & $45.38^{\mathrm{a}} \pm 1.02$ \\
Q20 & $225.4^{\mathrm{c}} \pm 7.1$ & $128.7^{\mathrm{c}} \pm 3.9$ & $5.0^{\mathrm{d}} \pm 0.3$ & $43.37^{\mathrm{b}} \pm 1.04$ \\
Q30 & $190.1^{\mathrm{d}} \pm 4.1$ & $131.5^{\mathrm{b}} \pm 3.7$ & $5.5^{\mathrm{d}} \pm 0.4$ & $42.24^{\mathrm{c}} \pm 0.09$ \\
Q40 & $197.1^{\mathrm{d}} \pm 3.3$ & $114.1^{\mathrm{d}} \pm 4.4$ & $5.5^{\mathrm{d}} \pm 0.6$ & $42.20^{\mathrm{c}} \pm 0.11$ \\
\hline
\end{tabular}

Legend: Table shows mean values and standard deviations; mean values in columns denoted by different letters differ significantly $(\mathrm{p}<0.05)$.

Different proportions of wholemeal gluten-free flours added to wheat flour resulted in a change of the colour of bread crumb (Table 4). Lightness L* of each variant was found to decrease on substituting wheat flour with gluten-free flour Moreover, within particular groups of variants an increased proportion of glutenfree flour increased lightness loss. The breads with gluten-free flours were darker, thus their color resembled commercially available wholemeal breads (Kurek et al. 2017; Mialon et al. 2002). Dark bread is much more often chosen by consumers due to the growing awareness of the presence of health-promoting compounds in whole flour, and consequently in the bread made from it (Bakke $\boldsymbol{\&}$ Vickers 2007; Heiniö et al. 2016). The intensity of the red colour (a*) also changed; it increased when quinoa and amaranth flours were added. Millet flour contributed to a slight increase of the intensity of green in the bread crumb. The analysis of balance between yellow and blue $\left(b^{*}\right)$ revealed that adding quinoa flour slightly shifted the colours towards blue, whereas the other flours shifted the colours towards yellow. On the basis of the obtained colour values the total colour difference $\Delta \mathrm{E}$ was determined. Available literature data suggest that consumers, even without expert knowledge, perceive the colour difference $\Delta \mathrm{E}$ ranging from 2 to 3.5 (Mokrzycki and Tatol 2011). Total colour difference, in reference to traditional bakery products, ranged from 2.96 for A10 to as much as 16.78 for $\mathrm{Q} 40$, which proves that changes in bread colour are clearly visible.

Table 4 Color determinants and total color difference $(\Delta \mathrm{E})$ of crumb bread

$\begin{array}{ccccc}\text { Sample } & \mathbf{L}^{*} & \mathbf{a}^{*} & \mathbf{b}^{*} & \Delta \mathbf{E} \\ \text { C } & 75.62^{\mathrm{a}} \pm 1.21 & 0.55^{\mathrm{d}} \pm 0.04 & 18.05^{\mathrm{b}} \pm 2.71 & - \\ \text { M10 } & 73.16^{\mathrm{b}} \pm 2.95 & 0.55^{\mathrm{d}} \pm 0.03 & 19.70^{\mathrm{b}} \pm 1.17 & 2.96 \\ \text { M20 } & 71.01^{\mathrm{b}} \pm 1.92 & 0.48^{\mathrm{d}} \pm 0.09 & 22.38^{\mathrm{a}} \pm 1.94 & 6.32 \\ \text { M30 } & 71.71^{\mathrm{b}} \pm 1.27 & 0.35^{\mathrm{d}} \pm 0.07 & 22.95^{\mathrm{a}} \pm 2.04 & 6.27 \\ \text { M40 } & 70.34^{\mathrm{b}} \pm 1.13 & 0.16^{\mathrm{e}} \pm 0.07 & 24.62^{\mathrm{a}} \pm 1.82 & 8.44 \\ \text { A10 } & 70.86^{\mathrm{b}} \pm 1.17 & 1.92^{\mathrm{b}} \pm 0.24 & 20.08^{\mathrm{ab}} \pm 1.93 & 5.35 \\ \text { A20 } & 66.05^{\mathrm{c}} \pm 2.71 & 3.12^{\mathrm{a}} \pm 0.47 & 21.13^{\mathrm{a}} \pm 2.06 & 10.38 \\ \text { A30 } & 63.50^{\mathrm{d}} \pm 1.92 & 4.02^{\mathrm{a}} \pm 0.97 & 21.43^{\mathrm{a}} \pm 1.76 & 13.39 \\ \text { A40 } & 62.07^{\mathrm{e}} \pm 2.08 & 4.65^{\mathrm{a}} \pm 0.91 & 21.74^{\mathrm{a}} \pm 2.31 & 14.97 \\ \text { Q10 } & 68.01^{\mathrm{c}} \pm 2.01 & 1.14^{\mathrm{c}} \pm 0.14 & 18.48^{\mathrm{b}} \pm 2.24 & 7.64 \\ \text { Q20 } & 65.25^{\mathrm{d}} \pm 1.33 & 1.34^{\mathrm{c}} \pm 0.11 & 17.66^{\mathrm{bc}} \pm 1.61 & 10.41 \\ \text { Q30 } & 61.94^{\mathrm{e}} \pm 2.47 & 1.72^{\mathrm{b}} \pm 0.27 & 17.61^{\mathrm{c}} \pm 1.11 & 13.87 \\ \text { Q40 } & 58.96^{\mathrm{f}} \pm 2.28 & 2.09^{\mathrm{b}} \pm 0.31 & 16.77^{\mathrm{c}} \pm 1.08 & 16.78\end{array}$

Legend: Table shows mean values and standard deviations; mean values in columns denoted by different letters differ significantly $(\mathrm{p}<0.05)$.

Gluten proteins in wheat bread are responsible for its proper structure (Demichelis et $\boldsymbol{a l}$. 2019) and reducing its quantity can significantly affect the characteristics of bread. Smaller bread volume entailed changes in the structure of bread crumb. The analysis of photographs of the bread crumb (Fig. 1) revealed considerable differences in porosity and pore distribution. Pore walls became thicker and the structure more compacted when the proportion of gluten-free flours increased. The differences may stem from the fact that gluten-free flours have a different chemical composition and, consequently, alter the content of the protein responsible for dough leavening during fermentation. The addition of hydrocolloids or milk protein seems to be an effective method of counteracting volume loss (Gallagher et al. 2003; Lazaridou et al. 2007).
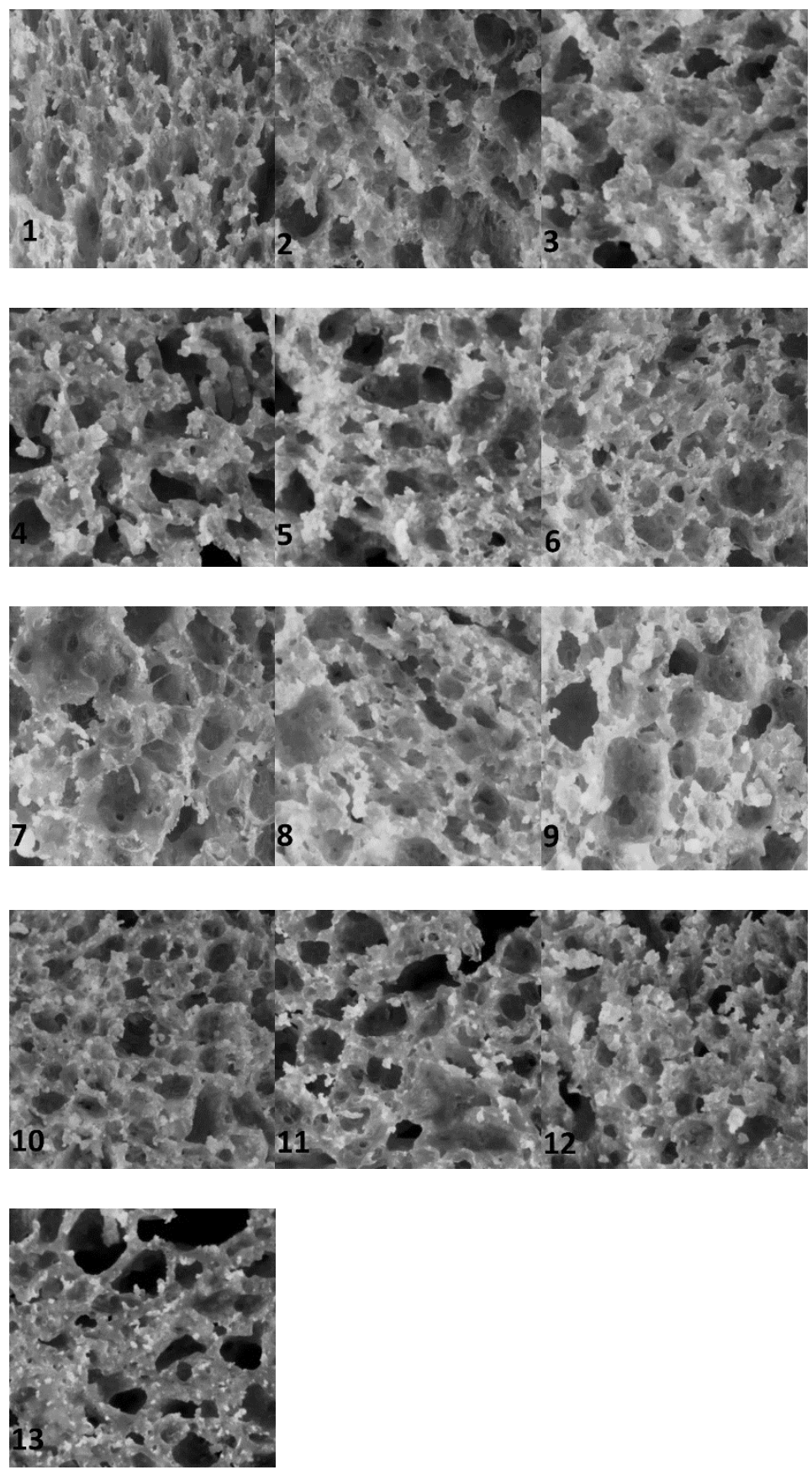

Figure 1 Photos of crumb porosity 1-13 respectively: C, A10, A20, A30, A40, M10, M20, M30, M40, Q10, Q20, Q30, Q40

Different proportions of gluten-free flours were found to affect texture of the crumb of baked bread (Table 5). Appropriate porosity and elasticity of the crumb is guaranteed by high content of starch in the dough and low content of dietary fibre (Deora et al. 2015). Including gluten-free flours in the recipes apparently increased firmness of the bread crumb. Due to high fibre content of quinoa seeds (twice higher than that of wheat grain), wheat-quinoa breads were noticeably firmer than other variants of bread. 
Table 5 Texture of bread analyzed

\begin{tabular}{ccc}
\hline Sample & $\begin{array}{c}\text { Springiness } \\
{[\%]}\end{array}$ & $\begin{array}{c}\text { Hardness } \\
{[\mathbf{N}]}\end{array}$ \\
\hline C & $72.45^{\mathrm{e}} \pm 1.56$ & $10.69^{\mathrm{g}} \pm 0.75$ \\
M10 & $96.58^{\mathrm{a}} \pm 0.30$ & $10.96^{\mathrm{g}} \pm 1.68$ \\
M20 & $95.97^{\mathrm{a}} \pm 1.14$ & $12.47^{\mathrm{f}} \pm 0.99$ \\
M30 & $92.36^{\mathrm{c}} \pm 1.07$ & $19.42^{\mathrm{cd}} \pm 3.49$ \\
M40 & $82.01^{\mathrm{d}} \pm 1.48$ & $22.97^{\mathrm{c}} \pm 3.15$ \\
A10 & $94.56^{\mathrm{b}} \pm 0.98$ & $11.03^{\mathrm{g}} \pm 0.96$ \\
A20 & $92.36^{\mathrm{c}} \pm 0.67$ & $18.15^{\mathrm{d}} \pm 2.02$ \\
A30 & $72.11^{\mathrm{e}} \pm 1.06$ & $23.07^{\mathrm{c}} \pm 1.90$ \\
A40 & $71.94^{\mathrm{e}} \pm 0.98$ & $26.06^{\mathrm{b}} \pm 2.23$ \\
Q10 & $98.16^{\mathrm{a}} \pm 0.06$ & $13.53^{\mathrm{f}} \pm 1.25$ \\
Q20 & $98.10^{\mathrm{a}} \pm 0.33$ & $16.73^{\mathrm{e}} \pm 1.97$ \\
Q30 & $97.05^{\mathrm{a}} \pm 0.09$ & $23.83^{\mathrm{c}} \pm 3.84$ \\
Q40 & $96.42^{\mathrm{a}} \pm 0.35$ & $35.75^{\mathrm{a}} \pm 3.33$ \\
\hline
\end{tabular}

Legend: Table shows mean values and standard deviations; mean values in columns denoted by different letters differ significantly $(\mathrm{p}<0.05)$.

Evaluation of total antioxidant activity becomes more and more important as it provides useful information on health-related and functional properties of raw materials without analysis of individual antioxidant compounds (Scalfi $\boldsymbol{e t}$ al. 2000). Antioxidant activity was more potent in case of all gluten-free flours (Table 6), and it increased with higher content of gluten-free flours. Phenolic compounds, especially phenolic acids, are found mainly in the seed coating (Tang and Tsao 2017). In the present study, whole-grain gluten-free flours were used, and the expected result would be a significant increase in the content of polyphenolic compounds in the breads obtained. However, only wholemeal quinoa flour appeared to be the only type of flour which significantly increased polyphenolic content of baked breads, as compared to wheat bread. Published research on quinoa seeds led to the identification of 23 phenolic compounds in free or conjugated forms, most of which were phenolic acids consisting of vanillic acid, ferulic acid and their derivatives, as well as flavonoids, quercetin, kaempferol and their glycosides (Tang et al. 2015; 2016). Also the highest antioxidant activity was exhibited by bread with $40 \%$ quinoa content. Polyphenolic compounds are sensitive to heat, therefore they are subject to degradation upon baking. The total antioxidant activity is changed even at mixing and kneading of the dough, probably due to enzymatic activity increasing when water was added to flour (Holtekjølen et al. 2008; Leenhardt et al. 2006).

Table 6 Total phenolic content and antioxidant activity of bread analyzed

\begin{tabular}{ccc}
\hline Sample & $\begin{array}{c}\text { Total phenolic content } \\
{[\boldsymbol{\mu g} / \mathbf{g} \text { DM] }}\end{array}$ & $\begin{array}{c}\text { Antioxidant properties } \\
{[\boldsymbol{\mu m o l} \text { Trolox/g DM] }}\end{array}$ \\
\hline C & $2.9^{\mathrm{e}} \pm 0.03$ & $2.82^{\mathrm{g}} \pm 0.14$ \\
M10 & $2.1^{\mathrm{j}} \pm 0.01$ & $2.98^{\mathrm{f}} \pm 0.02$ \\
M20 & $2.4^{\mathrm{h}} \pm 0.01$ & $3.54^{\mathrm{c}} \pm 0.05$ \\
M30 & $2.5^{\mathrm{g}} \pm 0.01$ & $3.98^{\mathrm{b}} \pm 0.07$ \\
M40 & $2.7^{\mathrm{f}} \pm 0.01$ & $4.02^{\mathrm{b}} \pm 0.03$ \\
A10 & $2.3^{\mathrm{i}} \pm 0.02$ & $2.87^{\mathrm{g}} \pm 0.09$ \\
A20 & $2.4^{\mathrm{h}} \pm 0.04$ & $3.01^{\mathrm{f}} \pm 0.06$ \\
A30 & $2.4^{\mathrm{h}} \pm 0.01$ & $3.03^{\mathrm{f}} \pm 0.07$ \\
A40 & $2.5^{\mathrm{g}} \pm 0.02$ & $3.33^{\mathrm{d}} \pm 0.06$ \\
Q10 & $3.6^{\mathrm{d}} \pm 0.03$ & $3.21^{\mathrm{e}} \pm 0.02$ \\
Q20 & $5.8^{\mathrm{c}} \pm 0.01$ & $3.65^{\mathrm{c}} \pm 0.08$ \\
Q30 & $6.1^{\mathrm{b}} \pm 0.06$ & $3.97^{\mathrm{b}} \pm 0.11$ \\
Q40 & $7.3^{\mathrm{a}} \pm 0.03$ & $4.21^{\mathrm{a}} \pm 0.09$ \\
\hline
\end{tabular}

Legend: Table shows mean values and standard deviations; mean values in columns denoted by different letters differ significantly $(\mathrm{p}<0.05)$.

\section{CONCLUSION}

Partial replacement of wheat flour with gluten-free flours altered the process of starch gelatinisation of the bread blends. The temperature of gelatinisation were higher in doughs with gluten-free flour addition compared to the control sample. It was also shown that viscosity significantly decreased due to the use of amaranth flour. Presumably, this is related to the high protein and fat content of this raw material. The colour of baked bread differed from the control bread; the bread crumb was darker (value of parameter $L^{*}$ ), and the balance of colours was shifted (value of parameters $a^{*}$ and $b^{*}$ ). The bread obtained as a result of the replacement of wheat flour with gluten-free flours resembled wholemeal bread, widely recognized as healthier. Changes were observed in the texture of baked bread as crumb firmness increased with higher content of gluten-free flours Adding quinoa and amaranth flours increased elasticity of bread crumb. The reduction of the gluten protein content resulted in impeding the creation of the proper structure and obtaining a crumb with a smaller porosity. Whole-wheat gluten-free flours are a source of antioxidant compounds, which is why a significant increase in the antioxidant activity of breads with these flours was observed. The increase was proportional to the content of gluten-free flour.

\section{REFERENCES}

AACC. (2009a). AACCI 10-05.01 Guidelines for Measurement of Volume by Rapeseed Displacement. In AACC International Approved Methods. AACC International. https://doi.org/10.1094/AACCIntMethod-10-05.01

AACC. (2009b). AACCI 44-19.01 Moisture--Air-Oven Method, Drying at 135 degrees. In AACC International Approved Methods. AACC International. https://doi.org/10.1094/AACCIntMethod-44-19.01

AACC. (2009c). AACCI 74-09.01 Measurement of Bread Firmness by Universal Testing Machine. In AACC International Approved Methods. AACC International. https://doi.org/10.1094/AACCIntMethod-74-09.01

AYO, J. A. (2001). The effect of amaranth grain flour on the quality of bread. International Journal of Food Properties, 4(2), 341-351. https://doi.org/10.1081/JFP-100105198

BAKKE, A., \& VICKERS, Z. (2007). Consumer Liking of Refined and Whole Wheat Breads. Journal of Food Science, 72(7), S473-S480. https://doi.org/10.1111/j.1750-3841.2007.00440.x

BREWER, G. J. (2007). Iron and Copper Toxicity in Diseases of Aging, Particularly Atherosclerosis and Alzheimer's Disease. Experimental Biology and Medicine, 232(2), 323-335. https://doi.org/10.3181/00379727-207-2320323

CADET, J., SAGE, E., \& DOUKI, T. (2005). Ultraviolet radiation-mediated damage to cellular DNA. Mutation Research/Fundamental and Molecular Mechanisms of Mutagenesis, 571(1-2), 3-17. https://doi.org/10.1016/j.mrfmmm.2004.09.012

COMAI, S., BERTAZZO, A., BAILONI, L., ZANCATO, M., COSTA, C. V. L., \& ALLEGRI, G. (2007). The content of proteic and nonproteic (free and proteinbound) tryptophan in quinoa and cereal flours. Food Chemistry, 100(4), 1350 1355. https://doi.org/10.1016/j.foodchem.2005.10.072

DE FLORA, S., \& IZZOTTI, A. (2007). Mutagenesis and cardiovascular diseases. Mutation Research/Fundamental and Molecular Mechanisms of Mutagenesis, 621(1-2), 5-17. https://doi.org/10.1016/j.mrfmmm.2006.12.008 DEMICHELIS, M., VANZETTI, L. S., CRESCENTE, J. M., NISI, M. M., PFLÜGER, L., BAINOTTI, C. T., ... HELGUERA, M. (2019). Significant effects in bread-making quality associated with the gene cluster Glu-D3/Gli-D1 from the bread wheat cultivar Prointa Guazú. Cereal Research Communications, 47(1), 111-122. https://doi.org/10.1556/0806.46.2018.055

DEORA, N. S., DESWAL, A., \& MISHRA, H. N. (2015). Functionality of alternative protein in gluten-free product development. Food Science and $\begin{array}{llll}\text { Technology } & \text { International, } & \text { 364-379), }\end{array}$ https://doi.org/10.1177/1082013214538984

ESCUDERO, N. L., DE ARELlANO, M. L., LUCO, J. M., GIMENEZ, M. S., \& MUCCIARELLI, S. I. (2004). Comparison of the Chemical Composition and Nutritional Value of Amaranthus cruentus Flour and Its Protein Concentrate. Plant Foods for Human Nutrition, 59(1), 15-21. https://doi.org/10.1007/s11130004-0033-3

FANG, Z., ZHANG, M., SUN, Y., \& SUN, J. (2006). How To Improve Bayberry (Myrica rubra Sieb. et Zucc.) Juice Color Quality: Effect of Juice Processing on Bayberry Anthocyanins and Polyphenolics. Journal of Agricultural and Food Chemistry, 54(1), 99-106. https://doi.org/10.1021/jf0519430

GALLAGHER, E., GORMLEY, T., \& ARENDT, E. (2003). Crust and crumb characteristics of gluten free breads. Journal of Food Engineering, 56(2-3), 153161. https://doi.org/10.1016/S0260-8774(02)00244-3

GARCÍA SALCEDO, A. J., TORRES VARGAS, O. L., \& ARIZA CALDERÓN, H. (2018). Physical-chemical characterization of quinoa (Chenopodium quinoa Willd.), amaranth (Amaranthus caudatus L.), and chia (Salvia hispanica L.) flours and seeds. Acta Agronómica, 67(2), 215-222. https://doi.org/10.15446/acag.v67n2.63666

GRAFENAUER, S., \& CURTAIN, F. (2018). An Audit of Australian Bread with a Focus on Loaf Breads and Whole Grain. Nutrients, 10(8), 1106 https://doi.org/10.3390/nu10081106

HEINIÖ, R. L., NOORT, M. W. J., KATINA, K., ALAM, S. A., SOZER, N., DE KOCK, H.L., HERSLETH, M., \& POUTANEN, K. (2016). Sensory characteristics of wholegrain and bran-rich cereal foods - A review. Trends in $\begin{array}{llll}\text { Food Science } \quad \text { \& } & \text { Technology, } & 47, & 25-38\end{array}$ https://doi.org/10.1016/j.tifs.2015.11.002

HEMALATHA, P., BOMZAN, D. P., SATHYENDRA RAO, B. V., \& SREERAMA, Y. N. (2016). Distribution of phenolic antioxidants in whole and milled fractions of quinoa and their inhibitory effects on $\alpha$-amylase and $\alpha$ glucosidase activities. Food Chemistry, 199, 330-338. https://doi.org/10.1016/j.foodchem.2015.12.025

HOLTEKJØLEN, A. K., BÆVRE, A. B., RØDBOTTEN, M., BERG, H., \& KNUTSEN, S. H. (2008). Antioxidant properties and sensory profiles of breads containing barley flour. Food Chemistry, 110(2), 414-421. https://doi.org/10.1016/j.foodchem.2008.02.054 
HOSSEN, M. S., SOTOME, I., TAKENAKA, M., ISOBE, S., NAKAJIMA, M., \& OKADOME, H. (2011). Effect of Particle Size of Different Crop Starches and Their Flours on Pasting Properties. Japan Journal of Food Engineering, 12(1), 29-35. https://doi.org/10.11301/jsfe.12.29

KALINOVA, J., \& MOUDRY, J. (2006). Content and Quality of Protein in Proso Millet (Panicum miliaceum L.) Varieties. Plant Foods for Human Nutrition, 61(1), 43-47. https://doi.org/10.1007/s11130-006-0013-9

KOWALCZEWSKI, P., RÓŻAŃSKA, M., MAKOWSKA, A., JEŻOWSKI, P., $\&$ KUBIAK, P. (2019). Production of wheat bread with spray-dried potato juice: Influence on dough and bread characteristics. Food Science and Technology International, 25(3), 223-232. https://doi.org/10.1177/1082013218814605

KUREK, M. A., WYRWISZ, J., KARP, S., BRZESKA, M., \& WIERZBICKA, A. (2017). Comparative analysis of dough rheology and quality of bread baked from fortified and high-in-fiber flours. Journal of Cereal Science, 74, 210-217. https://doi.org/10.1016/j.jcs.2017.02.011

LAMACCHIA, C., MUSAICO, D., HENDERSON, M. E., BERGILlOSMECA, T., ROUL, M., LANDRISCINA, L., ... COSTABILE, A. (2018). Temperature-treated gluten proteins in Gluten-FriendlyTM bread increase mucus production and gut-barrier function in human intestinal goblet cells. Journal of Functional Foods, 48, 507-514. https://doi.org/10.1016/j.jff.2018.07.047 LAZARIDOU, A., DUTA, D., PAPAGEORGIOU, M., BELC, N., \& BILIADERIS, C. G. (2007). Effects of hydrocolloids on dough rheology and bread quality parameters in gluten-free formulations. Journal of Food Engineering, 79(3), 1033-1047. https://doi.org/10.1016/j.jfoodeng.2006.03.032 LEENHARDT, F., LYAN, B., ROCK, E., BOUSSARD, A., POTUS, J. CHANLIAUD, E., \& REMESY, C. (2006). Wheat Lipoxygenase Activity Induces Greater Loss of Carotenoids than Vitamin E during Breadmaking. Journal of Agricultural and Food Chemistry, 54(5), 1710-1715. https://doi.org/10.1021/jf052243m

LEUSCHNER, R. G. K., O'CALLAGHAN, M. J. A., \& ARENDT, E. K. (1997) Optimization of baking parameters of part-baked and rebaked Irish brown soda bread by evaluation of some quality characteristics. International Journal of Food Science \& Technology, 32(6), 487-493. https://doi.org/10.1111/j.13652621.1997.tb02122.x

MAKOWSKA, A., KUBIAK, P., BIALAS, W., \& LEWANDOWICZ, G. (2015) Effect of urea, sodium nitrate and ethylene glycol addition on the rheological properties of corn starch pastes. Polimery, 60(05), 343-350. https://doi.org/10.14314/polimery.2015.343

MAKOWSKA, A., SZWENGIEL, A., KUBIAK, P., \& TOMASZEWSKAGRAS, J. (2014). Characteristics and structure of starch isolated from triticale. Starch - Stärke, 66(9-10), 895-902. https://doi.org/10.1002/star.201300264 MIALON, V. S., CLARK, M. R., LEPPARD, P. I., \& COX, D. N. (2002). The effect of dietary fibre information on consumer responses to breads and "English" muffins: a cross-cultural study. Food Quality and Preference, 13(1), 112. https://doi.org/10.1016/S0950-3293(01)00051-9

MOKRZYCKI, W., \& TATOL, M. (2011). Color difference Delta E - A survey. Machine Graphics and Vision, 20, 383-411.

MONDAL, A., GURIA, T., MAITY, T., \& BISHAYEE, A. (2016). A Novel Tetraenoic Fatty Acid Isolated from Amaranthus spinosus Inhibits Proliferation and Induces Apoptosis of Human Liver Cancer Cells. International Journal of Molecular Sciences, 17(10), 1604. https://doi.org/10.3390/ijms17101604

O'CONNOR, A. (2012). An overview of the role of bread in the UK diet. Nutrition Bulletin, 37(3), 193-212. https://doi.org/10.1111/j.14673010.2012.01975.x

PAUTER, P., RÓŻAŃSKA, M., WIZA, P., DWORCZAK, S., GROBELNA, N., SARBAK, P., \& KOWALCZEWSKI, P. Ł. (2018). Effects of the replacement of wheat flour with cricket powder on the characteristics of muffins. Acto Scientiarum Polonorum Technologia Alimentaria, 17(3), 227-233. https://doi.org/10.17306/J.AFS.2018.0570

PERRY, G., CASH, A. D., SRINIVAS, R., \& SMITH, M. A. (2002). Metals and oxidative homeostasis in Alzheimer's disease. Drug Development Research, 56(3), 293-299. https://doi.org/10.1002/ddr.10099

RE, R., PELLEGRINI, N., PROTEGGENTE, A., PANNALA, A., YANG, M., \& RICE-EVANS, C. (1999). Antioxidant activity applying an improved ABTS radical cation decolorization assay. Free Radical Biology and Medicine, 26(910), 1231-1237. https://doi.org/10.1016/S0891-5849(98)00315-3

RYBICKA, I., DOBA, K., \& BIŃCZAK, O. (2019). Improving the sensory and nutritional value of gluten-free bread. International Journal of Food Science \& Technology, https:///oi.org/10.1111/ijfs.14190

SCALFI, L., FOGLIANO, V., PENTAGELO, A., GRAZIANI, G., GIORDANO, I., \& RITIENI, A. (2000). Antioxidant activity and general fruit characteristics in different ecotypes of Corbarini small tomatoes. Journal of Agricultural and Food Chemistry, 48, 1363-1366. https://doi.org/10.1021/jf990883h

SEIFRIED, H. E., ANDERSON, D. E., FISHER, E. I., \& MILNER, J. A. (2007). A review of the interaction among dietary antioxidants and reactive oxygen species. The Journal of Nutritional Biochemistry, 18(9), 567-579. https://doi.org/10.1016/j.jnutbio.2006.10.007

SULLIVAN, P., O'FLAHERTY, J., BRUNTON, N., ARENDT, E., \& GALLAGHER, E. (2011). The utilisation of barley middlings to add value and health benefits to white breads. Journal of Food Engineering, 105(3), 493-502. https://doi.org/10.1016/j.jfoodeng.2011.03.011

SUN-WATERHOUSE, D. \& WADHWA, S. S. (2013). Industry-relevant approaches for minimising the bitterness of bioactive compounds in functional foods: A review. Food and Bioprocess Technology, 6, 607-627. https://doi.org/10.1007/s11947-012-0829-2

TANG, Y., LI, X., ZHANG, B., CHEN, P. X., LIU, R., \& TSAO, R. (2015) Characterisation of phenolics, betanins and antioxidant activities in seeds of three Chenopodium quinoa Willd. genotypes. Food Chemistry, 166, 380-388. https://doi.org/10.1016/j.foodchem.2014.06.018

TANG, Y., \& TSAO, R. (2017). Phytochemicals in quinoa and amaranth grains and their antioxidant, anti-inflammatory, and potential health beneficial effects: a review. Molecular Nutrition \& Food Research, 61(7), 1600767. https://doi.org/10.1002/mnfr.201600767

TANG, Y., ZHANG, B., LI, X., CHEN, P. X., ZHANG, H., LIU, R., \& TSAO, R. (2016). Bound Phenolics of Quinoa Seeds Released by Acid, Alkaline, and Enzymatic Treatments and Their Antioxidant and $\alpha$-Glucosidase and Pancreatic Lipase Inhibitory Effects. Journal of Agricultural and Food Chemistry, 64(8), 1712-1719. https://doi.org/10.1021/acs.jafc.5b05761

VALKO, M., RHODES, C. J., MONCOL, J., IZAKOVIC, M., \& MAZUR, M. (2006). Free radicals, metals and antioxidants in oxidative stress-induced cancer. Chemico-Biological Interactions, $\quad 160(1), \quad 1-40$. https://doi.org/10.1016/j.cbi.2005.12.009

VENSKUTONIS, P. R., \& KRAUJALIS, P. (2013). Nutritional Components of Amaranth Seeds and Vegetables: A Review on Composition, Properties, and Uses. Comprehensive Reviews in Food Science and Food Safety, 12(4), 381-412. https://doi.org/10.1111/1541-4337.12021 